DOI: 10.2478/orga-2014-0020

\title{
Outline of Implemented Eco-innovation Activities - the Case of Clusters of South Eastern European Region
}

\author{
Jana Hojnik', Mitja Ruzzier ${ }^{1}$, Aleš Lipnik ${ }^{2}$ \\ ${ }^{1}$ Faculty of Management, University of Primorska, Cankarjeva 5, 6000 Koper, Slovenia, \\ jana.hojnik@fm-kp.si, mitja.ruzzier@fm-kp.si \\ ${ }^{2}$ University of Primorska, Science and Research Centre of Koper, Garibaldijeva 1, 6000 Koper, Slovenia, \\ ales.lipnik@zrs.upr.si
}

\begin{abstract}
Background and Purpose: Providing a win-win situation for enterprises and the environment is raising the importance of eco-innovation. This article sheds light on the eco-innovation activities implemented within the clusters of the South Eastern European region (hereafter the SEE region). The main objective of this paper is to provide an outline of the situation pertaining to the implementation of eco-innovation activities in analyzed clusters.

Methodology: Empirical evidence is provided through the performance of survey research with a sample of 52 clusters, encompassing 11 countries of the SEE region. The basic research method used in this research was a questionnaire developed for cluster organizations, with which we gathered the data and afterwards conducted descriptive statistics.

Results: The findings demonstrate that the majority of analyzed clusters implement eco-innovation activities. The results indicate that 40 clusters out of 52 in all have set objectives with regard to eco-innovation support in their national or regional programs, followed by 35 clusters, which include objectives related to eco-innovation in their cluster strategies, and lastly, only 15 clusters are primarily focused on eco-innovation. Hence, our study depicting the current situation regarding the implementation of eco-innovation activities in analyzed clusters and clusters' orientation towards eco-innovation leads to us the discussion of why such differences in clusters occur.

Conclusion: The huge differences related to the implementation of eco-innovation activities in clusters of the SEE region, can also reflect the level of the national/regional development in terms of economic indicators such as GDP and, at the same time, offer room for a lot of improvement, and an exchange of best practice.
\end{abstract}

Keywords: eco-innovation, clusters, SEE region

\section{Introduction}

The main goal of this paper is to depict the actual situation regarding activities related to the eco-innovation implemented in analyzed clusters, by encompassing 11 countries of South Eastern European region (henceforth SEE region). Our study derives from a project called Cluster PoliSEE (http://www.clusterpolisee.eu/) and provides an outline of the current situation regarding the implementation of eco-innovation activities in analyzed clusters and their orientation towards eco-innovation.
We are thus following Porter's (1998: p. 78) definition of clusters: “... geographic concentrations of interconnected companies and institutions in a particular field. Clusters encompass an array of linked industries and other entities important to competition. They include, for example, suppliers of specialized inputs such as components, machinery and services, and providers of specialized infrastructure. Clusters also often extend downstream to channels and customers and laterally to manufactures of complementary products and to companies in industries related by skills, technologies, or common inputs. Finally, many clusters include

Received: June 6th, 2014; revised: August 8th 2014; accepted; September 11th, 2014 
governmental and other institutions - such as universities, standards-setting agencies, think tanks, vocational training providers and trade associations - that provide specialized training, education, information and technical support".

Moreover, Tessitore et al. (2010), based on a study of industrial clusters, proved that eco-innovation has the potential and power to strengthen the resilience of those enterprises of the cluster, which in a longer run show the ability to upgrade their strategic and managerial behavior in order to align with the most competitive challenges (here authors also count in environmental excellence). While Porter (1998) argues that clusters play a key role in enterprises' ongoing ability to innovate and have also a vital role in being critical towards competition and impact competition in the following three ways: firstly, through the increased productivity of enterprises based in the area (enterprises which are a part of a cluster can operate more productively in sourcing inputs - better access to suppliers and employees; access of technology, information and needed institutions; coordination of related companies), secondly, clusters drive the pace and the direction of innovation, which is the underpin of future productivity growth and, thirdly, clusters induce the formation of new businesses, which expand and consequently strengthen the cluster itself (Porter 1998).

In our study, we have focused on eco-innovation activities performed in clusters. Therefore, we have posed questions regarding eco-innovation activities practiced among analyzed clusters and their orientation towards eco-innovation. We aimed to delineate the clusters' orientation towards eco-innovation and review those eco-innovation activities, which are introduced among the analyzed clusters of the SEE region. In the second chapter of this paper, we will put emphasis on the benefits, which can be captured through the successful implementation of eco-innovations and present the eco-innovation's peculiarities and its definition as well. The remainder of this article is structured as follows: section three presents the methodology and, further ahead, in section four, we reveal the results of the study leading to section 5 , which offers a discussion of the results and concludes with the limitations of the study and future research directions.

\section{Theoretical background of eco- innovation}

Due to the enterprises' negative impact on the environment, leading to serious global environmental problems, a global concern for the environment has also increased among researchers. Thereby, the topic of eco-innovation is gaining importance. Eco-innovation can be described as any new or significantly improved product (good or service), process, organizational change or marketing solution which results in the reduction of the use of natural resources (including materials, energy, water and land) and decreases the release of harmful substances across the lifecycle (EIO 2010 in EIO 2013). Gmelin and Seuring (2014) have emphasized the is- sue of sustainability and pinpointed that management should pay more attention to it, especially when it concerns new product development. Therefore, Pujari et al. (2003) stated that the logic of the design, for the environment approach, means that new environmental product development is not a radically different process compared to the conventional one. However, by adding a further level of complexity, this process must continue to deliver core benefits to customers, while also addressing stakeholder needs for improved eco-performance and manage any necessary trade-offs with existing core or auxiliary product benefits (Pujari et al. 2003: p.658).

Moreover, in order to reach a sustainable new product development, both lifecycle management and product lifecycle management should be involved (Gmelin and Seuring 2014). While, Pujari (2006) revealed that the factors, which affect market performance of greener products are found to be cross-functional co-ordination between new product development professionals and environmental specialists, supplier involvement, market focus and lifecycle analysis. When focusing on drivers of sustainable product development, Tsai et al. (2012) revealed that an important factor for the new product development strategy for green toys is customer benefit. However, Gmelin and Seuring (2014) suggested that there are both, internal and external triggers that motivate the sustainable development of new products.

Researchers also endeavored to delineate how and why eco-innovations differ from other innovations and argued that eco-innovations have to be properly researched as well. Rennings, already back in year 2000, emphasized the "double externality problem" of eco-innovations as its peculiarity and pinpointed that eco-innovations are triggered by the regulatory push/pull effect, which is not a common driver of other innovation types. All innovations produce common knowledge spillovers, while eco-innovations additionally bring positive externalities to those - environmental spillovers that result in the fact that society benefits from them, while the costs are borne by the enterprises, which practice and introduce eco-innovations (Rennings et al. 2006). In order to define eco-innovation, many attempts have been made, while Angelo et al. (2012: p. 117), following a literature review, have proposed the following definition of eco-innovation: "Eco-innovations are organizational implementations and changes focusing on the environment, with implications to companies' products, manufacturing processes and marketing, with different degrees of novelty. They can be merely incremental improvements that intensify the performance of something that already exists, or radical ones that promote something completely unprecedented, where the main objective is to reduce the company's environmental impacts".

However, eco-innovations, through bringing benefits to the environment and to the enterprise, create a so called "win-win" situation (Horbach 2008). Therefore, we should be interested in how enterprises can successfully compete in changing markets and environments (Klewitz and Hansen 2013). Eco-innovations are oriented towards a whole 
lifecycle of products, processes etc. with the aim of releasing less harmful substances into the environment through its production and thus harm the environment less - resulting in a reduction in environmental impact (Fraj-Andrés et al. 2009; Angelo et al. 2012; Horbach, Rammer and Rennings 2012; EIO 2010 in EIO 2013). Enterprises with successful implementation of eco-innovations can seize several benefits. One of those benefits is the gain of a competitive advantage (Shrivastava 1995; Tien et. al 2005; Chen et al. 2006; Triebswetter and Wackerbauer 2008; Fraj-Andrés et al. 2009; Ar 2012; Hofer et al. 2012; Mourad and Ahmed 2012; Wong 2012; Leonidou et al. 2013 Robinson and Stubberud 2013).

Other benefits derived from the eco-innovation deployment are eco-efficiency (Mourad and Ahmed 2012) and an improved firm's reputation (Shrivastava 1995). Eco-innovation also leads to improved firm performance (Clemens 2006; Zeng et al. 2011; Doran and Ryan 2012; Cheng et al. 2013; Cruz-Cázares et al. 2013; Rexhäuser and Rammer 2013). Moreover, the gain of sustainable growth in the domestic and international markets (European commission 2012), internationalization and improved export performance (Beise and Rennings 2005; Gurău and Ranchhod 2005; Martin-Tapia et al. 2008; Martin-Tapia et al. 2010; Cassiman and Golovko 2011; Aguilera-Caracuel et al. 2012; D'Angelo et al. 2013) are also among the benefits derived from successful eco-innovation implementation.

\section{Methodology}

The following results derive from a study, which has been conducted within the framework of the Cluster PoliSEE Project, comprising 11 countries (including: Albania, Austria, Bulgaria, Croatia, Greece, Hungary, Italy, Romania, Serbia, Slovakia and Slovenia). The main aim of this project (Cluster PoliSEE) was to enhance the capability of policy makers to confront the situation in the field of entrepreneurial connections in clusters, predicting development and preventing non-desirable changes in entrepreneurial clusters' operations.

Data was gathered with a questionnaire applied to cluster organizations and consisted of closed questions, in our case regarding eco-innovation activities in cluster organizations. The main purpose of this questionnaire was to get a deeper understanding of eco-innovation adoption and successful implementation in analyzed clusters, followed by the identification of the main activities related to eco-innovation from the perspective of cluster managers. The theoretical background for the questionnaire development was found in scientific articles about clusters, different reports and studies about clusters in different European countries (Asheim 1996; Swann et al. 1998; Raines 2000; Diez 2001; Sölvell et al. 2003; Andersson et al. 2004; OECD 2007) as well as including some conceptualization. The questionnaire used in the project entitled Cluster PoliSEE was checked and redeveloped several times within the group members respon- sible for this activity (AWS Austria, Ecoplus, Austria and UP ZRS). The applied questionnaire was developed in the English language, which was also the language in which the respondents had to fill them out. The target respondent group for the questionnaire for cluster organizations (regarding eco-innovation activities) consisted of 3-4 clusters that partners deem "representative" in their country. Further on in our analysis, we will see that some countries or regions (in the case of Italy) included more than four clusters in the analyses and some just one.

The data collection method was that of a personal interview (or telephone interview if it was not possible to perform a personal one). The questionnaire was sent at least one week in advance so that cluster managers were able to prepare for the interview and inform respondents about the time needed. The respondents were cluster managers. Data was collected from 22 November 2012 to 22 January 2013 (approximately two months). To eliminate the bias of different interviewers, a unified Excel form was developed to fill in the answers to the questionnaire. This allowed us to have data that is more comparable across countries and regions for further analyses.

We have used general descriptive statistics in order to present the results of the study. No other more advanced statistical procedures were used for data analyses because of the small sample size and interpretative nature of the article (overview of the current situation regarding eco-innovation's activities).

\subsection{Questionnaire description}

Our study derived from the project entitled Cluster PoliSEE. We have focused on the part that pertains to eco-innovation (comprising four questions with regard to eco-innovation activities) in the analyzed clusters, all from the SEE region. The respondents were, as aforementioned, cluster managers.

We have obtained general information regarding the eco-innovation activities with the following questions: 1) "Does the regional/national cluster program set any objectives with regard to support of eco-innovation?", 2) "Does your cluster strategy include any objectives related to eco-innovation?" and 3) "Is your cluster primarily focused on eco-innovation and, therefore, carries out a wide range of activities related to eco-innovation?".

Clusters were also urged to indicate what kind of activities related to eco-innovation they implement. The listed eco-innovation activities were the following: 1) Awareness-raising, 2) Distribution of information, 3) Training, 4) Support for introduction of eco standards, 5) Support for investments to improve eco-friendliness, 6) Initiation of/participation in eco $R \& D$ projects. The scale of the sum variable thus ranges from zero (no eco-innovation activity carried out) to six (all listed eco-innovation activities carried out). 


\section{Results}

Firstly, we present the results for all countries together regarding orientation towards eco-innovation in the analyzed clusters of the SEE region and then in Table 1, we demonstrate results focusing on each single country. As second, we show the results focused on implementation of activities related to eco-innovation, followed by implemented eco-innovation activities within clusters of each single country. Our sample encompasses 52 clusters deriving from 11 countries, which have participated in the Cluster PoliSEE project. In more details, the number of questionnaires, which we received and were completed by cluster managers in each separate country (or in regions in case of Italy) are as follows: Albania (1 questionnaire), Austria (2 questionnaires), Bulgaria (4 questionnaires), Croatia (3 questionnaires), Greece (5 questionnaires), Hungary (3 questionnaires), Italy - Emilia Romagna region (8 questionnaires), Italy - Marche region (4 questionnaires), Italy - Veneto region (1 questionnaire), Romania (8 questionnaires), Serbia (5 questionnaires), Slovakia (4 questionnaires) and Slovenia (4 questionnaires).

Clusters that were comprised in our study deal with different area of operation/industries: tourism, textile, shoes, wood, pellet, energy, automotive, technology, dental and health tourism, biotechnology/pharmaceuticals and medical technology, green building, green construction, software, metal industry, wine promotion, furniture, electro-mobile, ICT, marine, organic agriculture, green energy, innovation (high-tech) and creative industry. The average number of cluster members in selected countries/region in year 2012 per cluster was 70, while the median was 34 cluster members. Moreover, average cluster structure is composed mainly of micro $(42 \%)$ and small $(30 \%)$ companies. These are followed by medium companies $(10 \%)$, large companies $(6 \%)$ and public bodies and intermediaries $(7 \%)$. Financial institutions, R\&D institutes, training and education providers, universities and technical colleges are represented just with a few members and just in certain countries.

\subsection{Clusters' orientation towards eco-inno- vation}

The overall results (see Figure 1) point out that 40 clusters from 52 participating clusters have confirmed that their national or regional cluster programs have set objectives with regard to eco-innovation support, therefore, just 12 of 52 clusters have answered that their regional or national cluster programs have not set any objectives related to the support of eco-innovation yet. Moreover, 35 clusters include objectives related to eco-innovation in their cluster strategies, while 17 of 52 analyzed clusters have not yet included any objectives related to eco-innovation. At last, 15 clusters primarily focus on eco-innovation and carry out a wide range of activities related to eco-innovation.

Furthermore, focusing on separate countries we can see from
Table 1 that in Albania and Veneto region (Italy) national or regional cluster programs have not set any objectives related to the support of eco-innovation yet. On contrary, we can see that all clusters of the Emilia Romagna region (Italy), Serbia (all five clusters), Marche region - Italy (all four clusters), Slovenia (all 4 clusters), Bulgaria (all four clusters) and Croatia (all three clusters) have confirmed that objectives related to eco-innovation support deriving from national or regional programs have been set.

Nonetheless, a high number of positive responses regarding the setting of objectives related to the support of eco-innovation in regional or national programs can be seen in the following countries: Slovakia (three of four clusters), Greece (three of five clusters), Romania (three of eight clusters) and Hungary (two of three clusters).

In addition, it also shows how many clusters from each single country include objectives related to eco-innovation in their cluster strategies. Thus, Table 1 illustrates that in Serbia and in Marche region (Italy) all of the analyzed clusters in both cases include objectives related to eco-innovation in their cluster strategies. These are followed by seven clusters (from eight in total) from region Emilia Romagna (Italy), which include in their cluster strategies the objectives related to eco-innovation.

Also, in the following countries the majority of the analyzed clusters from each country include objectives related to eco-innovation in their cluster strategies: Croatia (two clusters out of three), Greece (three clusters out of five), Slovakia (three clusters out of four) and Slovenia (three clusters out of four). In Austria, Bulgaria and also Romania we can see that $50 \%$ of analyzed clusters include the objectives related to eco-innovation in their cluster strategy. In Hungary, just one cluster includes the objectives related to eco-innovation in their cluster strategies. Lastly, in Albania and the Veneto region (Italy) no cluster includes the objectives related to eco-innovation in their cluster strategies.

In the last column of Table 1, we can see how many clusters in each country primarily focus on eco-innovation and carry out a wide range of activities related to it. In Albania, Hungary, Veneto region (Italy) and Serbia, no cluster primarily focuses on eco-innovation. While in Marche region (Italy), the primary focus on eco-innovation is presented in three clusters out of four in total. Additionally, the countries where the primary focus on eco-innovation is presented in $50 \%$ of the analyzed clusters are the following: Austria (one cluster of two in total), region Emilia Romagna from Italy (four clusters of eight in total) and Slovakia (two clusters of four in total).

Table 1 presents frequencies regarding positive responses of all the analyzed clusters joined together for each country (e.g. in the last column the results depict how many clusters within the analyzed ones from each country are primarily focused on eco-innovation). 
Does the regional/national cluster program set any objectives with regard to the support to eco-innovation

Does your cluster strategy include any objectives related to eco-innovation

Is your cluster primarily focused on ecoinnovation

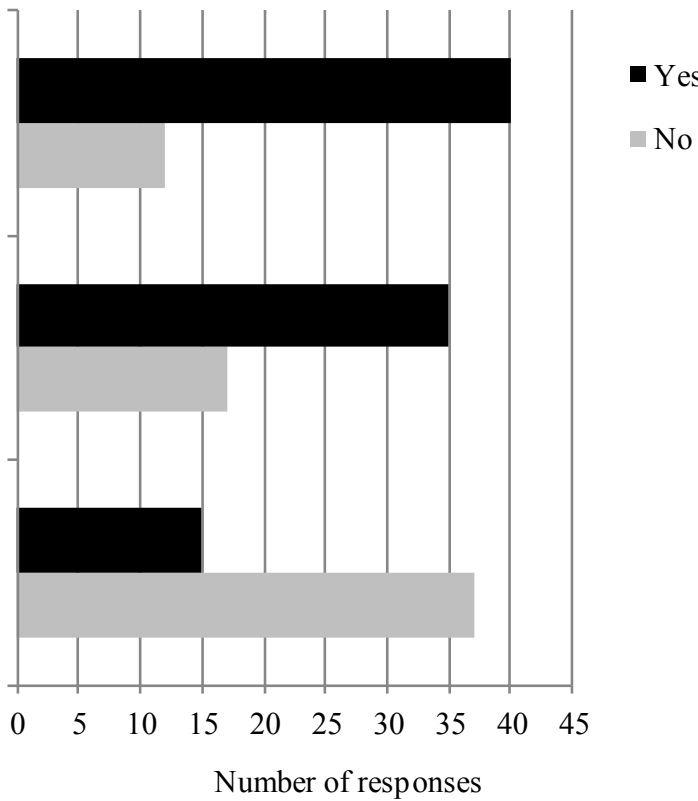

Figure 1: Orientation towards eco-innovation within the analyzed clusters of the SEE region (for the overall sample). (Source: Authors)

\subsection{Clusters' implementation of eco-in- novation activities}

In the second part of the results, we focus on eco-innovation activities implemented in the analyzed clusters. The overall results (see Figure 2) indicate that among the listed activities related to eco-innovation, analyzed clusters in majority carry out the following activities: initiation of/participation in eco R\&D projects (42 clusters), followed by training (41 clusters), distribution of information (41 clusters) and awareness-raising (41 clusters). However, the activities which are related to eco-innovation and less carried out by all the analyzed clusters are the support for the introduction of eco standards (39 clusters) and the support for investments to improve eco-friendliness (38 clusters). While the least implemented activities related to eco-innovation in the analyzed clusters are classified in the category other (eight clusters), meaning that the analyzed clusters do not implement many other activities related to eco-innovation besides the listed ones.

Moreover, we present the results regarding the implementation of activities related to eco-innovation in the clusters of each participated country (the results are presented/ displayed in frequencies for each country, meaning that frequencies for every single eco-innovation activity have been computed through all the analyzed clusters for each country separately). Here we have to emphasize the fact that the Albanian cluster and the cluster from Veneto region (Italy) do not implement any of the listed eco-innovation activities, therefore, the figure is blank when regarding them and this presents a total absence of activities related to eco-innovation.

The results (see Figure 3) have revealed that Austrian clusters implement all activities related to eco-innovation to the same extent ( 1 for each one), while they do not engage in activities related to the support for investments to improve eco-friendliness. Bulgarian clusters implement to the largest extent the activities regarding training (3) and distribution of information (3), while the least implemented eco-innovation activities of Bulgarian clusters are the support to introducing eco standards (1) and other $(1=$ extended life cycle standards). The most implemented activities related to eco-innovation in Croatian clusters are initiation of/participation in eco R\&D projects (2) and distribution of information (2), while all the other listed activities related to eco-innovation are implemented to a lower extent ( 1 for each activity related to eco-innovation). Meanwhile, Greek clusters mostly implement activities such as: initiation of/participation in eco R\&D projects (3) and training (3), while all other activities related to eco-innovation in Greek clusters are less implemented ( 2 for each eco-innovation activity).

The most implemented activities related to eco-innovation in Hungarian clusters are: awareness-raising (1), distribution of information (1), support to introducing eco standards (1) and support for investments to improve eco-friendliness (1). The activities such as inititation of participation in eco R\&D projects and training are completely absent in Hungarian clusters. Regarding Italy, the analyzed clusters deriving from Emilia Romagna region (Italy) 
mostly implement activities such as awareness-raising (6) and distribution of information (6), followed by the least practiced activity which is training (2).

However, in the Marche region (Italy) clusters implement to the same extent the following activities related to eco-innovation: awareness-raising (3), distribution of information (3), training (3), initiation of/participation in eco R\&D projects (3) and support for introduction of eco standards (3), while the least implemented activity is the support for investments to improve eco-friendliness (2). Furthermore, initiation of/participation in eco R\&D projects (4), awareness-raising (4) and distribution of information (4) are eco-innovation activities, which are mostly implemented in Romanian clusters. They engage the least in supporting investments to improve eco-friendliness (1).
Moreover, awareness-raising (5) and distribution of information (5) are implemented to the largest extent in Serbian clusters, while training (1) is implemented to the lowest extent. We can see that Slovak clusters mostly implement the following activities: awareness-raising (4) and distribution of information (4), while they do not engage in supporting investments to improve eco-friendliness. Lastly, the most implemented activities regarding eco-innovation within the scope of Slovenian clusters are: awareness-raising (4), distribution of information (4), followed by the least implemented activity, which is classified as other ( $1=$ development of assessment criteria for sustainable building). In addition, Slovenian clusters also do not implement any support to investments to improve eco-friendliness.

Table 1: Orientation towards eco-innovation within the analyzed clusters of the SEE region (presented for the participating countries).

\begin{tabular}{|c|c|c|c|c|}
\hline & $\begin{array}{c}\text { Number of } \\
\text { analyzed } \\
\text { clusters }\end{array}$ & $\begin{array}{c}\text { Does the regional / } \\
\text { national cluster program } \\
\text { set any } \\
\text { objectives with } \\
\text { regard to the support to } \\
\text { eco-innovation }\end{array}$ & $\begin{array}{l}\text { Does your } \\
\text { cluster strategy } \\
\text { include any } \\
\text { objectives } \\
\text { related to eco- } \\
\text { innovation }\end{array}$ & $\begin{array}{l}\text { Is your cluster } \\
\text { primarily } \\
\text { focused on eco- } \\
\text { innovation }\end{array}$ \\
\hline Albania & 1 & 0 & 0 & 0 \\
\hline Austria & 2 & 1 & 1 & 1 \\
\hline Bulgaria & 4 & 4 & 2 & 1 \\
\hline Croatia & 3 & 3 & 2 & 1 \\
\hline Greece & 5 & 3 & 3 & 1 \\
\hline Hungary & 3 & 2 & 1 & 0 \\
\hline $\begin{array}{c}\text { Emilia Romagna region } \\
\text { (Italy) }\end{array}$ & 8 & 8 & 7 & 4 \\
\hline $\begin{array}{l}\text { Marche region } \\
\quad \text { (Italy) }\end{array}$ & 4 & 4 & 4 & 3 \\
\hline Veneto region (Italy) & 1 & 0 & 0 & 0 \\
\hline Romania & 8 & 3 & 4 & 1 \\
\hline Serbia & 5 & 5 & 5 & 0 \\
\hline Slovakia & 4 & 3 & 3 & 2 \\
\hline Slovenia & 4 & 4 & 3 & 1 \\
\hline
\end{tabular}




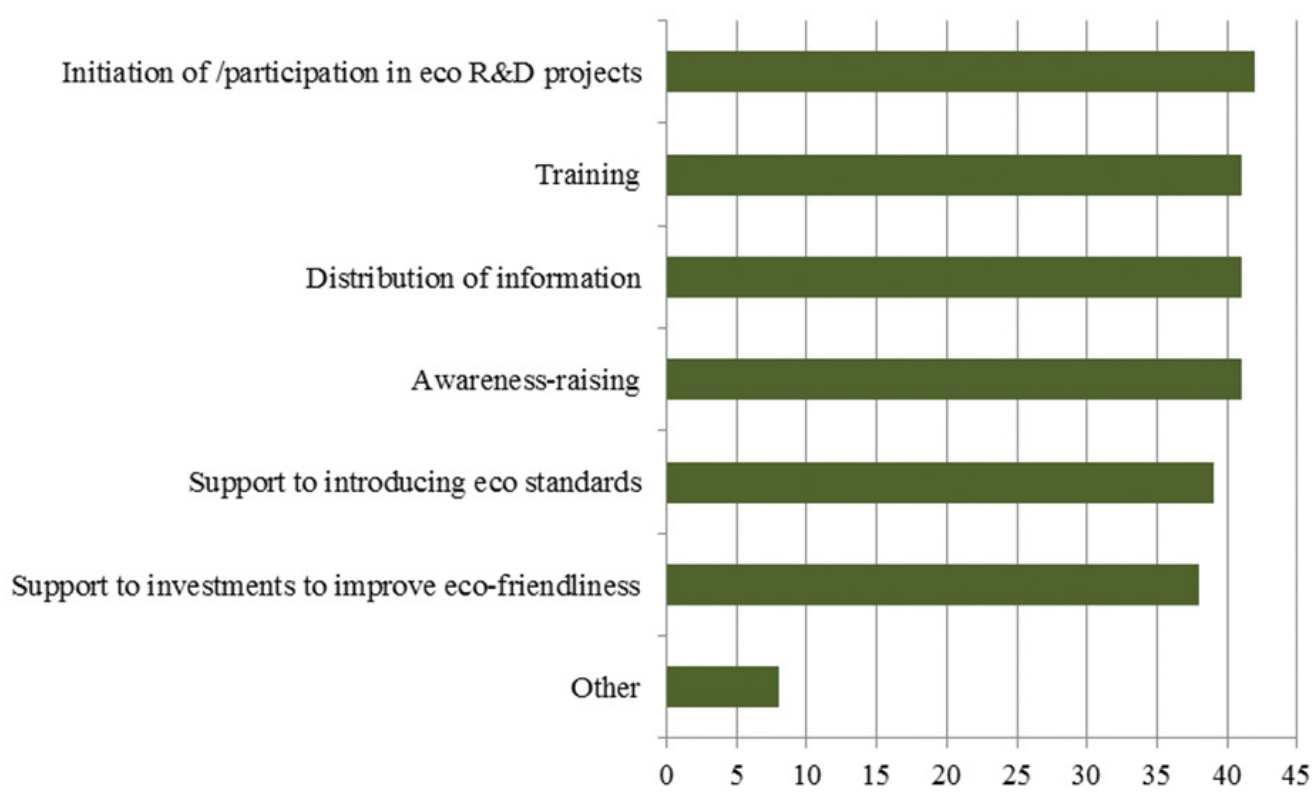

Figure 2: Implemented eco-innovation activities in the analyzed clusters of countries from the SEE region (Source: Authors).

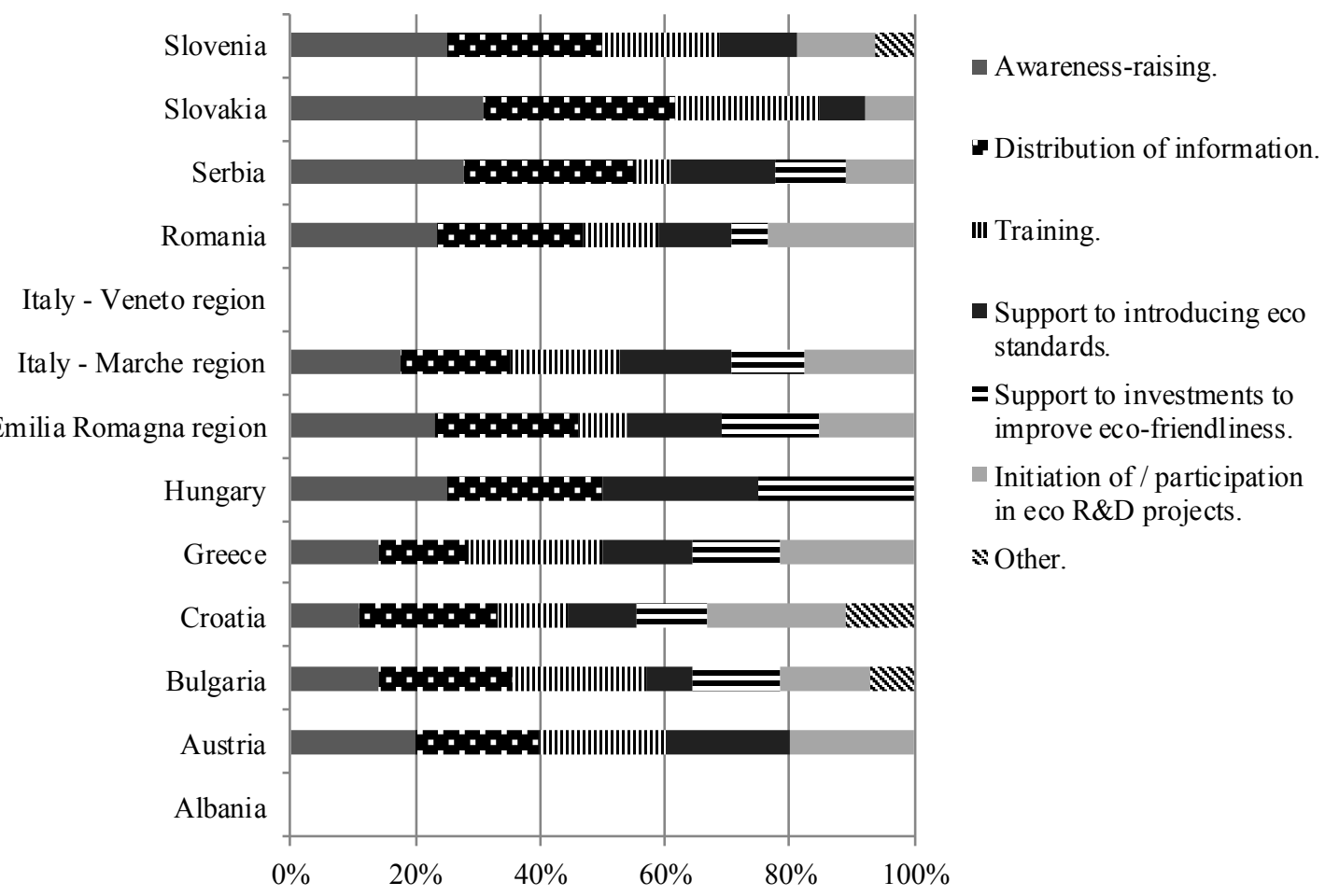

Figure 3: IEco-innovation activities implemented in the analyzed clusters (in frequencies) of 11 countries, encompassing the SEE region (Source: Authors). 
TAble 2: Descriptive statistics (median values, mean values and standard deviations) regarding the implemented eco-innovation activities in the analyzed clusters of the SEE region

\begin{tabular}{|c|c|c|c|}
\hline & $\begin{array}{c}\text { Median value } \\
(\mathbf{M e})\end{array}$ & $\begin{array}{c}\text { Mean value } \\
(\mathbf{M})\end{array}$ & Standard deviation (SD) \\
\hline Albania & 0,00 & 0,00 & 0,00 \\
\hline Austria & 0,50 & 0,42 & 0,20 \\
\hline Bulgaria & 0,50 & 0,54 & 0,19 \\
\hline Croatia & 0,33 & 0,44 & 0,17 \\
\hline Greece & 0,40 & 0,47 & 0,10 \\
\hline Hungary & 0,33 & 0,22 & 0,17 \\
\hline Emilia Romagna region (Italy) & 0,50 & 0,54 & 0,19 \\
\hline Marche region (Italy) & 0,75 & 0,71 & 0,10 \\
\hline Veneto region (Italy) & 0,00 & 0,00 & 0,00 \\
\hline Romania & 0,38 & 0,35 & 0,17 \\
\hline Serbia & 0,50 & 0,60 & 0,33 \\
\hline Slovakia & 0,50 & 0,54 & 0,43 \\
\hline Slovenia & 0,63 & 0,63 & 0,38 \\
\hline
\end{tabular}

\section{Discussion}

In this section, we first present and discuss clusters' implementation of eco-innovation activities based on average and median values for each country. Section 5 concludes with conclusions, limitations of this study and future research directions.

\subsection{Discussion regarding clusters' imple- mentation of eco-innovation activities}

In Table 2, we present descriptive statistics (median, mean and standard deviation) regarding the implementation of eco-innovations within the analyzed clusters of the SEE region. With an aim to delineate and in order to provide representative data for each country regarding the implementation of eco-innovation activities and to be able to compare them (at least roughly), we have estimated the presented descriptive statistics through two steps. Firstly, we have computed all eco-innovation activities in the analyzed clusters pertaining to every single type of eco-innovation activity separately for each country and divided them with a number of the analyzed clusters (to ensure that the mean value could be more representative, because the number of analyzed clusters varied among the countries).

Secondly, we have calculated mean values regarding the performed eco-innovation activities within different countries (for each country all types of eco-innovation activities were computed and then divided with the number of eco-in- novation activities $=$ six of them). Nonetheless, mean values could not reflect the actual situation - are not representative enough; we have used in addition the median values, which are far more appropriate in our case.

Additionally, Figure 4 illustrates the median values of eco-innovation activities performed in the analyzed clusters for each of the participating country. What we need to emphasize is, that these results are focused just on our sample, comprising the analyzed clusters, which have participated in the Cluster PoliSEE project. Hereby, we can see from Figure 4 that Marche region from Italy is a leader in the implementation of eco-innovation activities, when, regarding the median value, it is followed by Slovenia.

High median values with regard to the implementation of eco-innovation activities are represented also in the following countries: Austria, Bulgaria, Emilia Romagna region (Italy), Serbia and Slovakia (all of them with equal median value). These are followed by Greece and Romania. Meanwhile, Croatia and Hungary (both with equal value of median) demonstrate the lowest median values pertaining implementation of eco-innovation activities (focusing on the analyzed clusters). At this point, we need to emphasize also that Veneto region (Italy) and Albania have not reported any eco-innovation activities implemented in the analyzed clusters.

Even though that all countries, with exception of Albania and Veneto region (Italy), implement eco-innovation activities to a certain level (some of them to a higher and some of them to a lower extent), we can notice big differences among the analyzed clusters of the participating countries 


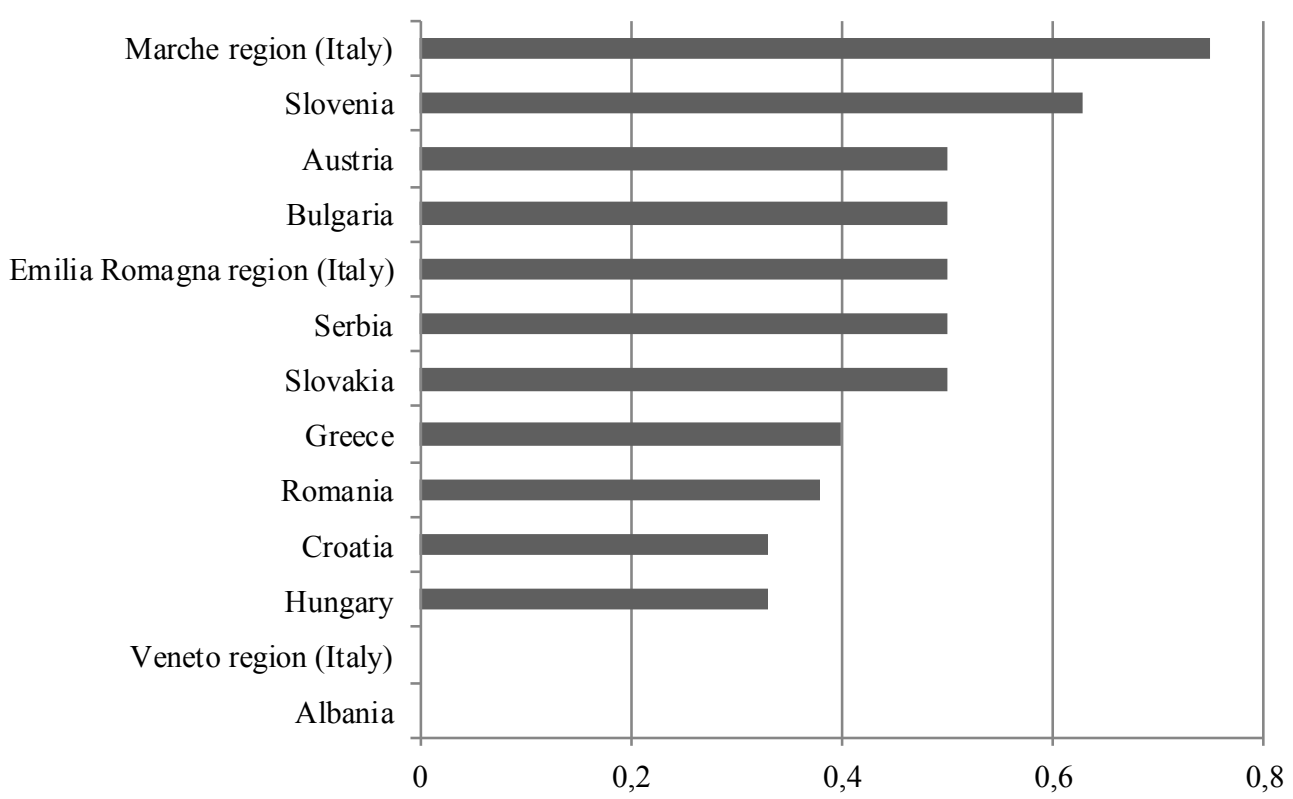

Figure 4: Median values of the implemented eco-innovation activities in the analyzed clusters of South Eastern European region countries. (Source: Authors)

(see Table 2 or Figure 4). These differences can also reflect the level of national/regional development in terms of economic indicators as GDP and the offer and at the same time a room for a lot of improvements, knowledge and best practices exchange. Albeit we think that, this is not the main reason for which such differences occur. Regarding mean values, we believe that some countries have probably not included the most representative clusters with regard to the implementation of eco-innovation activities. Perhaps these clusters were not eager to cooperate.

Therefore, a better explanation of the obtained results (especially pertaining to mean values) is that countries, which have participated in the study have not necessarily gathered the data from the most representative clusters in the country (note also that clusters encompassed in the analyses of the Cluster PoliSEE project were a personal choice of project partners) and this can lower mean values. In order to avoid this inconvenience we have presented also median values.

A surprising fact pertaining to the aforementioned discussion is also that Marche region (Italy) is the leader in our study regarding the performance of eco-innovation activities, also median and mean values of Emilia Romagna region (Italy) are still among high ones, while on contrary, Veneto region, also belonging to Italy, has not reported any eco-innovation activities at all. Here we posit the question. If clusters comprised in our study are not representative, why other (perhaps) more representative clusters have not participated in the study, if they exist? We interpret the results that derived from our study and emphasize that the number of clusters is too low to generalize the findings, but at least gives space to open a discussion how to motivate the most "representative" clusters to cooperate in studies.

In conclusion, the differences are largely under the impact of the representativeness of the analyzed clusters encompassed in the study. Because of an unequal number of the analyzed clusters from the countries comprised in our study, each eco-innovation activity was divided with a number of clusters in order to provide mean values that are slightly more suitable. Additionally, we have presented also median values and interpreted them.

Clusters provide both, competition and cooperation alike and, in addition to enhancing productivity, they play a crucial role in enterprise's ongoing ability to innovate (Porter 1998). Similarly, Lindqvist et al. (2013) stressed the relevance of clusters for innovation, especially because of a critical mass in a location of a sector or industry. Clusters have a better window on the market compared to their isolated competitors and, as well, they provide the capacity and the flexibility to act rapidly (Porter 1998). Their main advantage is that different actors can support each other and the effect of (un) planned meetings and interactions are new ideas (Lindqvist et al. 2013).

Moreover, over the time the concept of innovation has grown stronger in relation to clusters and in more organized clusters innovation is really at the heart of what clusters should be about (Lindqvist et al. 2013). This is in line with our results (see Table 1), where it can be seen that the majority of clusters confirm the setting of objectives with regard to the support of eco-innovation in their 
regional/national program and/or include those objectives in their cluster strategies. Some of them are also primarily focused on eco-innovation.

According to the theory, the presence or absence of eco-innovation priorities in cluster policies might be related partially to the wider policy framework and the support to eco-innovation available in each one of the countries (Barsoumian et al. 2011). Therefore, in countries where eco-innovation policy framework supports the development and uptake of eco-solutions or in countries that have older cluster policies, it is more likely that also eco-innovation cluster policies are in place (Barsoumian et al. 2011). However, we can see that countries with longer cluster policy history confirm setting of the objectives related to the eco-innovation support in their national/regional cluster programs, also in their cluster strategies they consequently implement eco-innovation activities to a greater extent, while the ones with the shorter cluster policy history are weaker in all of the aforementioned criteria.

Moreover, referring to our study, we can see also that our findings are consistent with the prior research and theory, which suggests that voluntary engagement of enterprises steers them towards greater implementation of eco-innovation (Doran and Ryan 2012). Therefore, clusters from countries, which confirm setting the objectives to the eco-innovation support in their regional/national cluster programs objectives, or include those objectives in their cluster strategies, or primarily focus on eco-innovation, implement also more eco-innovation activities and rank higher (with regard to the median values) compared to the ones that do not satisfy any of previously mentioned three conditions. Similarly, theory suggests that enterprise' strategies and their primary focus, which are set up in order to support eco-innovation, as a result induce the development of green products (Laperche and Uzunidis 2012).

In addition, Plambeck (2012) stress that enterprise' strategy has direct and indirect impact on its innovative behavior and, therefore, affects the level of innovativeness of the responses related to environmental changes. Our conclusion derived from this study, is that clusters have an important role in dissemination of eco-innovation activities within companies grouped in clusters and therefore, more emphasis should be given to implementation of the objectives related to the support of eco-innovation in their cluster strategies.

\subsection{Conclusion, limitations of the study and future research directions}

The major evidence arising from the analyses performed is the big difference regarding the level of cluster policy development and operations of cluster organizations that affects the clusters' implementation of eco-innovation activities as well. Therefore, the biggest challenge for policy makers will be in the lowering of such differences and in homogenization of operating conditions for clusters, with focused actions adapted to their level of development. One of the biggest opportunities lies in the knowledge transfer and the transfer of good practices from more to less developed regions/countries/cluster organizations. One potential solution to lower such disparities would also be in the development of focused international cluster networks, with an aim to transfer accumulated knowledge, good practices and experiences on different levels; policy makers, cluster organization's and cluster members.

One of the biggest limitations of this study is the huge difference in the level of development and operations of cluster policy and, therefore, it was hard to suggest some generalized conclusions. Being a limitation, big differences in the level of cluster policy bring at the same time also the opportunities for learning and improving them, especially with the possibility of knowledge transfer and implementation of best practices across countries and regions. The second limitation was the selection of "representative" clusters, proposed by project partners in their country/region, which is related also to the comparability of knowledge of the way in which the data collection was performed by different interviewers.

It was almost impossible to verify this element, because certain countries have very little clusters, with a short cluster policy history (e.g. Albania), while in other countries there is a rich cluster presence and "history". The next limitation concerns the sampling. Actually, project partners selected to interview the clusters they wished (they chose clusters that regarding to their opinion were the most representative in their country), but such cluster may not be really representative for their region or country. Therefore, the analyzed clusters were not chosen randomly, but according to the opinion of project partners (choosing the most representative ones among all clusters).

This is also related to the number of clusters in certain countries or region. In the less developed countries, actually, clusters just started "to establish" and it is expected they would deal with totally different problems and challenges than clusters in developed countries, with longer cluster policy tradition. The fourth limitation is pertaining to data analyses (because of very small sample size, just basic statistical methods have been used-in our case the descriptive statistics).

As well, the sample was quite small for conducting any more advanced analyzes. At the beginning, we have already emphasized that our study is merely an outline of the current situation, regarding the implementation of eco-innovation activities by analyzed clusters. Finally, the last limitation pertains to low response rate. Therefore, researchers should in future take into consideration the low response rate and discuss how to motivate more representative clusters to complete the questionnaires and also maintain the equal number of clusters from each country with a goal to avoid other problems occurring at the stage, when examining the results.

In future research work we should include a higher number of clusters and gain more information regarding the implementation of activities related to eco-innovation. 
This would contribute to the research field of eco-innovation in clusters and as well provide results, which could be generalized.

However, our study is a scan of the current situation and offers a lot of space to improve. In future, we could comprise information about eco-innovation activities in clusters and categorize them in eco-product, eco-process and eco-organizational innovation. Therefore, it would be meaningful to explore which factors drive each type of eco-innovation and which type of eco-innovation is more beneficial for clusters to implement. We could as well explore the barriers of deployment of eco-innovation in clusters and the factors that spur clusters in eco-innovation deployment. An interesting area of research could also comprise a new eco-product development - a research on how clusters approach it. An interesting point of research would also be exploration of the benefits, consequences that have been seized by clusters' successful implementation of eco-innovations.

\section{Acknowledgments}

This survey has been conducted within the framework of the Cluster Polisee project, program Interreg SEE.

We would like to thank all the contributors for the analyses including our colleagues from the University of Primorska, the Science and Research Centre: Maja Cergol Lipnik, Jure Ramšak, and Matej T. Vatovec.

Many thanks also to our Austrian colleagues from Austria Wirtschaftservice: Elfie Kober and Christine Winisch; as the work package leader AWS have done a great job, being a bridge between us and all the project partners, assuring the smooth workflow.

Also, we would like to thank Cristina Fritteloni from Svilupo Marche for her remarks and comments.

Moreover, we would like to address special thanks to all project partners from the Cluster Polisee project: Marche Region (Italy), Emilia Romagna Region (Italy), Veneto Region (Italy), Pannon Business Network Association (Hungary), Maribor Development Agency (Slovenia), The Bulgarian Small and Medium Enterprises Promotion Agency (Bulgaria), Union of Hellenic Chamber of Commerce (Greece), Region of Central Macedonia (Greece), Athena Research and Innovation Center in Information, Communication and Knowledge Technologies / Corallia Clusters Initiative Unit Corallia (Greece), AWS (Austria), Wirtschaftsservice Ltd. (Austria), Ecoplus - The business Agency of Lower Austria Ltd. (Austria), North East Regional Development Agency (Romania), Institute for Economic Forecasting (Romania), National authority for scientific research (Romania), The union of Slovak clusters (Slovakia), Trnava self-Governing Region (Slovakia), Ministry of economy of the Slovak republic (Slovakia), Hungarian Economic Development Centre (Hungary), Istrian Development Agency (Croatia), Provincial secretariat for Economy (Serbia), Albanian Investment Development Agency (Albania), University of Novi Sad (Serbia), Ministry of Economic Development - Department for Development and Economic Cohesion (Italy), Ministry of Economy, Commerce and Business Environment (Romania). We thank all for their work in collecting data and information from clusters, for their qualitative opinion, and also for their patience in dealing with all questionnaires, forms, instructions, and deadlines.

Finally, we also thank the two anonymous referees for helpful comments that improved the quality of this paper.

\section{Literature}

Aguilera-Caracuel, J., Hurtado-Torres, N. E., \& AragónCorrea, J. A. (2012). Does International Experience Help Firms to Be Green? A Knowledge-based View of How International Experience and Organisational Learning Influence Proactive Environmental Strategies. International Business Review, 21 (5), 847-861, http:// dx.doi.org/10.1016/j.ibusrev.2011.09.009

Andersson, T., Schwaag-Serger, S., Sörvik, J., \& Wise Hansson, E. 2004. The Cluster Policies Whitebook. Malmö: International Organisation for Knowledge Economy and Enterprise Development.

Angelo, F. D., Chiappetta, J., Charbel J., \& Vasconcellos, G. S. (2012). Environmental Innovation, In Search of a Meaning. World Journal of Entrepreneurship, Management and Sustainable Development, 8 (2/3), 113121, http://dx.doi.org/10.1108/20425961211247734

Ar, I. M. (2012). The Impact of Green Product Innovation on Firm Performance and Competitive Capability: The Moderating Role of Managerial Environmental Concern. Procedia - Social and Behavioral Sciences, 62, 854-864, http://dx.doi.org/10.1016/j.sbspro.2012.09.144

Asheim, B. T. (1996). Industrial Districts as 'Learning Regions': a Condition for Prosperity. European Planning Studies, 4 (4), 379 - 400.

Barsoumian, S., Severin, A., \& van der Spek. T. (2011). Eco-innovation and National Cluster Policies in Europe, a Qualitative Review. Report by Greenovate. Brussels: Greenovate! Europe EEIG, http://www.clusterobservatory.eu/eco/uploaded/ pdf/1315915223865.pdf

Beise, M., \& Rennings, K. (2005). Lead Markets and Regulation: a Framework for Analyzing the International Diffusion of Environmental Innovations. Ecological Economic, 52 (1), 5-17, http://dx.doi.org/10.1016/j. ecolecon.2004.06.007

Cassiman, B., \& Golovko, E. (2011). Innovation and internationalization through exports. Journal of International Business Studies, 42, 56-75.

Chen, Y.-S., Lai, S.-B., \& Wen, C.-T. (2006). The Influence of Green Innovation Performance on Corporate Advantage in Taiwan. Journal of Business Ethics, 67 (4), 331-339.

Cheng, C. C. J., Yang, C.-L., \& Sheu, C. (2013). The link between eco-innovation and business performance: 
a Taiwanese industry context. Journal of Cleaner Production, http://dx.doi.org/10.1016/j. jclepro.2013.09.050

Clemens, B. (2006). Economic Incentives and Small Firms: Does It Pay to Be Green? Journal of Business Research, 59 (4), 492-500, http://dx.doi.org/10.1016/j. jbusres.2005.08.006

Cruz-Cázares, C., Bayona-Sáez, C., \& García-Marco, T. (2013). You Can't Manage Right What You Can't Measure Well: Technological Innovation Efficiency. Research Policy. (April), http://dx.doi.org/10.1016/j. respol.2013.03.012

D’Angelo, A., Majocchi, A., Zucchella, A., \& Buck, T. (2013). Geographical Pathways for SME Internationalization: Insights from an Italian Sample. International Marketing Review, 30 (2), 80-105, http:// dx.doi.org/10.1108/02651331311314538

Diez, M. A. (2001). The Evaluation of Regional Innovation and Cluster Policies: Towards a Participatory Approach. European Planning Studies, 9 (7), 907-923, http://dx.doi. org/10.1080/0965431012007983

Doran, J. \& Ryan, G. (2012). Regulation and Firm Perception, Eco-innovation and Firm performance. European Journal of Innovation Management, 15 (4), 421-441, http://dx.doi.org/10.1108/14601061211272367

Eco-innovation Observatory (2013). Europe in transition: Paving the way to a green economy through ecoinnovation. Eco-Innovation Observatory. Brussels: DG Environment. Funded by the European Commission, http:/www.prodetur.es/prodetur/AlfrescoFileTransferSe rvlet?action=download\&ref=b2dd7229-79e8-4511-afef1d1e8644f983

European Commission (2012). Connecting Smart and Sustainable Growth through Smart Specialisation: A Practical Guide for ERDF Managing Authorities. Luxembourg: Publications office of the European Union, http://ec.europa.eu/regional_policy/sources/docgener/ presenta/green_growth/greengrowth.pdf

Fraj-Andrés E., Martinez-Salinas, E., \& Matute-Vallejo, J. (2009). A multidimensional approach to the Influence of Environmental's Marketing and Orientation on the Firm's Organizational Performance. Journal of Business Ethics, 88, 263-286, http://dx.doi.org/10.1007/s10551008-9962-2

Gmelin, H. \& Seuring, S. (2014). Determinants of a Sustainable New Product Development. Journal of Cleaner Production, 69(15 April), 1-9, http://dx.doi. org/10.1016/j.jclepro.2014.01.053

Gurău, C., \& Ranchhod, A. (2005). International Green Marketing: AComparative Study of British and Romanian Firms. International Marketing Review, 22 (5), 547-561, http://dx.doi.org/10.1108/02651330510624381

Hofer, C., Cantor, D. E., \& Dai, J. (2012). The Competitive Determinants of a Firm's Environmental Management Activities: Evidence from US Manufacturing Industries. Journal of Operations Management, 30 (1-2), 69-84, http://dx.doi.org/10.1016/j.jom.2011.06.002

Horbach, J. (2008). Determinants of Environmental
innovation-New Evidence from German Panel Data Sources. Research Policy, 37 (1), 163-173, http://dx.doi. org/10.1016/j.respol.2007.08.006

Horbach, J., Rammer, C., \& Rennings, K. (2012). Determinants of Eco-innovations by Type of Environmental Impact - The Role of Regulatory Push/ pull, Technology Push and Market Pull. Ecological Economics, 78, 112-122, http://dx.doi.org/10.1016/j. ecolecon.2012.04.005

Klewitz, J., \& Hansen, E. G. (2013). Sustainability-oriented Innovation of SMEs: a Systematic Review. Journal of Cleaner Production, 65(15 February), 57-75, http:// dx.doi.org/10.1016/j.jclepro.2013.07.017

Laperche, B. \& Uzunidis, D. (2012). Eco-Innovation, Knowledge Capital and the Evolution of the Firm. The IUP Journal of Knowledge Management, X (3), 14-35.

Leonidou, L. C., Katsikeas, C. S., Fotiadis, T. A., \& Christodoulides, P. (2013). Antecedents and Consequences of an Eco-Friendly Export Marketing Strategy : The Moderating Role of Competitive Intensity. Journal of International Marketing, 21 (3), 22-46.

Lindqvist, G., Ketels, C., \& Sölvell, Ö. (2013). The Cluster Initiative Greenbook 2.0. Stockholm: Ivory Tower Publishers.

Martin-Tapia, I., Aragon-Correa, J. A., \& Senise-Barrio, M. E. (2008). Being Green and Export Intensity of SMEs: The Moderating Influence of Perceived Uncertainty. Ecological Economics, 68 (1-2), 56-67, http://dx.doi. org/10.1016/j.ecolecon.2008.01.032

Martín-Tapia, I., Aragón-Correa, J. A., \& Rueda-Manzanares, A. (2010). Environmental Strategy and Exports in Medium, Small and Micro-enterprises. Journal of World Business, 45 (3), 266-275, http://dx.doi.org/10.1016/j. jwb.2009.09.009

Mourad, M. \& Ahmed, Y. S. E. (2012). Perception of Green Brand in an Emerging Innovative Market. European Journal of Innovation Management, 15 (4), 514-537, http://dx.doi.org/10.1108/14601061211272402

Organization for Economic Co-operation and Development. (2007). OECD Reviews of Regional Innovation, Competitive Regional Clusters, National Policy Approaches. Paris: OECD Publishing.

Plambeck, N. (2012). The Development of New Products: The Role of Firm Context and Managerial Cognition. Journal of Business Venturing, 27 (6), 607-621, http:// dx.doi.org/10.1016/j.jbusvent.2011.08.002

Porter, M. E. (1998). Clusters and the New Economics of Competition. Harvard Business Review. NovemberDecember, 77-90

Pujari, D., Wright, G., \& Peattie, K. (2003). Green and Competitive. Journal of Business Research, 56 (8), 657-671 http://dx.doi.org/10.1016/S0148-2963(01)00310-1

Pujari, D. (2006). Eco-Innovation and New Product Development: Understanding the Influences on Market Performance. Technovation, 26 (1), 76-85, http://dx.doi. org/10.1016/j.technovation.2004.07.006 
Raines, P. (2000). Developing Cluster Policies in Seven European Regions. Regional and Industrial Research Paper No. 42. Glasgow: European Policies Research Centre, University of Strathclyde.

Rennings, K. (2000). Redefining Innovation - Ecoinnovation Research and the Contribution from Ecological Economics. Ecological Economics, 32 (2), 319-332 http://dx.doi.org/10.1016/S09218009(99)00112-3

Rennings, K., Ziegler, A., Ankele, K., \& Hoffmann, E. (2006). The Influence of Different Characteristics of the EU Environmental Management and Auditing Scheme on Technical Environmental Innovations and Economic Performance. Ecological Economics, 57 (1), 45-59, http://dx.doi.org/10.1016/j.ecolecon.2005.03.013

Rexhäuser, S., \& Rammer, C. (2013). Environmental Innovations and Firm Profitability: Unmasking the Porter Hypothesis. Environmental and Resource Economics. (May 14), http://link.springer.com/10.1007/s10640-0139671-x

Robinson, S., \& Stubberud, H. A. (2013). Green innovation in Germany: a comparison by business size. Journal of International Business Research, 12 (1), 47-56.

Shrivastava, P.1. (1995). Environmental Technologies and Competitive Advantage. Strategic Management Journal, 16, 183-200.

Sölvell, Ö., Lindquist, G. \& Ketels, C. (2003). The Cluster Initiative Greenbook. Stockholm: Ivory Tower AB.

Swann, G. M. P., Prevezer, M., \& Stout, D. (1998). The Dynamics of Industrial Clustering: International Comparisons in Computing and Biotechnology. Oxford: Oxford University Press.

Tien, S.-W., Chung, Y.-C., \& Tsai, C.-H. (2005). An Empirical Study on the Correlation Between Environmental Design Implementation and Business Competitive Advantages in Taiwan's Industries. Technovation, 25 (7), 783-794, http://dx.doi.org/10.1016/j.technovation.2004.01.004

Tessitore, S., Daddi, T., \& Iraldo, F. (2010). Eco-Innovation and Economic Performance in Industrial Clusters: Evidence from Italy, https://waset.org/journals/waset/ v42/v42-232.pdf

Triebswetter, U., \& Wackerbauer, J. (2008). Integrated Environmental Product Innovation in the Region of Munich and Its Impact on Company Competitiveness. Journal of Cleaner Production, 16 (14), 1484-1493, http://dx.doi.org/10.1016/j.jclepro.2007.09.003

Tsai, M.-T., Chuang, L.-M., Chao, S.-T., \& Chang, H.-P. (2012). The Effects Assessment of Firm Environmental Strategy and Customer Environmental Conscious on Green Product Development. Environmental Monitoring and Assessment, 184 (7), 4435-47, http://dx.doi. org/10.1007/s10661-011-2275-4

Zeng, S.X., Meng, X.H., Zeng, R.C., Tam, C.M., Tam, Vivian
W.Y., \& Jin, T. (2011). How Environmental Management Driving Forces Affect Environmental and Economic Performance of SMEs: a Study in the Northern China District. Journal of Cleaner Production, 19 (13), 14261437, http://dx.doi.org/10.1016/j.jclepro.2011.05.002

Wong, S. K.-S. (2012). The Influence of Green Product Competitiveness on the Success of Green Product Innovation and Electronics Industry. European Journal of Innovation Management, 15 (4), 468-490, http:// dx.doi.org/10.1108/14601061211272385

Jana Hojnik is Research Assistant and Teaching Assistant of Entrepreneurship at the University of Primorska, Faculty of Management Koper, Slovenia. Her research interest encompasses research fields of innovation, eco-innovation and internationalization. She is a member of European Association of Environmental and Resource Economists (EAERE), and currently a PhD candidate at the Faculty of Management, University of Primorska.

Mitja Ruzzier is a Professor of Entrepreneurship at the University of Primorska, Faculty of Management Koper, Slovenia. He teaches different courses about entrepreneurship and international business at the undergraduate and post-graduate level. His research interest lies in the area of internationalization, international marketing, branding, innovation, SMEs and entrepreneurship. He has many practical experiences and he works part time as a consultant for many companies. His papers were published in different academic journals such as the Entrepreneurship and Regional Development, Transformations in Business and Economics, Managing Global Transition, Canadian Journal of Administrative Science, Journal of Small Business and Enterprise Development and others. He has published also different books about entrepreneurship. More information about the author is available on http://www.mitjaruzzier.com.

Aleš Lipnik is the Head of the Centre for Cooperation with the Economy at the University of Primorska, Science and Research Centre. His main field of work and research is oriented at innovation policy studies and services for supporting entrepreneurs (especially SMEs) and cooperation between industry and academia. He was/is a member of different regional, national and EU-based working, evaluating and expert groups from the field of innovation and economy. He has a rich, long-term, experiences in numbers of different EU-based projects from the field of innovation and economics. He teaches courses connected with his fields of expertise: project management, technology transfer, innovation and innovation policies, production management and innovation management. 